\title{
Perumusan Konsep Shariah Governance di Indonesia: Evaluasi Model Pengawasan Syariah di Sektor Perbankan
}

\author{
Laili Latifah Puspitasari ${ }^{1}$, Rifqi Muhammad ${ }^{2 *}$ \\ ${ }^{1}$ Sekolah Pascasarjana Universitas Gadjah Mada \\ ${ }^{2}$ Program Studi Akuntansi Universitas Islam Indonesia
}

Masuk: 10 Maret 2019; Diterima: 16 Juni 2019; Terbit: 20 Juni 2019

\begin{abstract}
This study aims to evaluate Sharia governance infrastructure in Sharia banking in Indonesia, specifically the Sharia review phase by the Sharia Supervisory Board which was disclosed in the Sharia bank annual report. Furthermore, an analysis of the possibility of adopting the Shariah Governance Framework (SGF) of Bank Negara Malaysia (BNM) is based on the perceptions of experts, using 3 research samples, namely Bank Syariah Mandiri, BPD DIY Sharia Business Unit, and BPRS Bhakti Sumekar. The data analysis uses a qualitative descriptive approach. Our results show that the governance processes, procedures and mechanisms in the Sharia review process by the DPS are supported by the bank's internal functions, namely the function of Internal Audit and the Compliance function. Based on these conditions, SGF BNM adoption is considered less suitable when applied to Islamic banking in Indonesia. One of them was caused by a lack of human resources in Indonesia with dual competency (Sharia law and finance). So that it is not possible to separate each unit such as the SGF BNM, namely Shariah Audit, Shariah Review, Shariah Research, and Shariah Risk Management.
\end{abstract}

Keywords: Islamic banks; shariah governance framework; shariah review

\begin{abstract}
Abstrak
Penelitian ini bertujuan untuk mengevaluasi infrastruktur tata kelola Syariah pada perbankan Syariah di Indonesia, khususnya tahap Shariah review oleh Dewan Pengawas Syariah yang diungkap pada laporan tahunan bank Syariah. Untuk selanjutnya dilakukan analisis kemungkinan adopsi Shariah Governance Framework (SGF) Bank Negara Malaysia (BNM) yang didasarkan pada persepsi para ahli dengan menggunakan 3 sampel penelitian, yaitu Bank Syariah Mandiri, Unit Usaha Syariah BPD DIY, dan BPRS Bhakti Sumekar. Analisis data menggunakan pendekatan deskriptif kualitatif. Hasil penelitian menunjukkan bahwa proses, prosedur, dan mekanisme tata kelola khususnya pada proses Shariah review oleh DPS didukung oleh fungsi internal bank, yaitu fungsi Audit Internal dan fungsi Kepatuhan. Berdasarkan kondisi tersebut, adopsi SGF BNM dinilai kurang sesuai apabila diterapkan pada perbankan Syariah di Indonesia. Hal tersebut salah satunya disebabkan oleh kurangnya jumlah sumber daya insani di Indonesia dengan dual competency (hukum Syariah dan keuangan). Sehingga belum memungkinkan untuk dilakukan pemisahan tiap unit seperti pada SGF BNM yaitu Shariah Audit, Shariah Review, Shariah Research, dan Shariah Risk Management.
\end{abstract}

Kata Kunci: perbankan syariah; kerangka tata kelola syariah; pengawasan syariah

* Corresponding author
E-mail : rifqimuhammad@uii.ac.id ${ }^{2}$ 


\section{PENDAHULUAN}

Tata kelola yang berlaku pada lembaga keuangan khususnya bank, memiliki karakteristik yang unik dibandingkan dengan tata kelola pada lembaga keuangan nonbank (Umam, 2016). Pada perbankan Syariah, diperlukan perhatian yang lebih besar karena ia dihadapkan pada banyaknya risiko ketidakpatuhan Syariah. Keberadaan Dana Pihak Ketiga menjadi bagian dari agency conflicts yang menanggung laba rugi sama seperti pemegang saham, menyebabkan urgensi mekanisme tata kelola Syariah yang andal untuk melindungi kepentingan dan kepercayaan mereka. Beragamnya pemangku kepentingan bank Syariah menjadi keniscayaan bank Syariah untuk mengungkap kegiatan tata kelola Syariahnya secara akurat dan transparan (Darmadi, 2013).

Dewan Pengawas Syariah (DPS) sebagai salah satu elemen kunci tata kelola bank Syariah, berperan dalam melakukan pengawasan penerapan fatwa pada praktik bank Syariah (ex post), tidak hanya pada proses persetujuan produk yang sesuai dengan prinsip Syariah (ex ante). Peran pengawasan kepatuhan Syariah ini tidak boleh diremehkan, mengingat risiko ketidakpatuhan Syariah yang mungkin terjadi pada bank Syariah. Perlu disadari bahwa pengawasan aspek ex post membutuhkan keahlian audit yang mungkin tidak dimiliki masing-masing anggota DPS. Selain itu, mungkin DPS tidak memiliki waktu untuk melakukan fungsi tersebut secara terperinci, sehingga pendelegasian tugastugas ke organ-organ tata kelola lain dalam organisasi, seperti audit internal atau unit Shariah review internal menjadi hal yang umum (CISI, 2010).

Praktik yang efektif dari tata kelola membutuhkan semua pihak yang terlibat untuk melaksanakan tanggungjawab sebaik mungkin dengan dukungan infrastruktur dalam bentuk prosedur, proses, dan mekanisme pengawasan (Mohamad, Shori, \& Shah, 2015). Faktanya, pedoman tata kelola untuk lembaga keuangan Syariah dalam bentuk Peraturan Bank Indonesia dan Surat Edaran Bank Indonesia belum memadai untuk digunakan sebagai kerangka tata kelola Syariah. Pada peraturan tersebut, sistem tata kelola Syariah masih berupa sub bagian yang mengerucut pada Dewan Pengawas Syariah. Dimana pelaksanaan fungsi ex post khususnya pada struktur Shariah review internal tidak dijelaskan secara khusus (Rama, 2015) .

Lain halnya dengan Shariah Governance Framework (SGF) yang diterbitkan oleh Bank Negara Malaysia (BNM), ketentuan tersebut bersifat komprehensif dan terintegrasi sebagai pedoman pelaksanaan tata kelola Syariah. SGF memiliki beberapa fungsi khusus yaitu Shariah audit, Shariah review, Shariah research, dan Shariah risk management, yang menunjang kinerja DPS dalam melaksanakan fungsi ex post. Karena fungsi utama SGF adalah mengoptimalkan fungsi DPS dalam hal menjamin kepatuhan Syariah lembaga keuangan Syariah.

Dengan infrastruktur regulasi yang lengkap dan dukungan dari pemerintah, Malaysia boleh dibilang berhasil dalam menerapkan SGF pada dunia praktiknya. Keberhasilan kebijakan SGF yang diterbitkan oleh BNM digarisbawahi oleh fakta bahwa yurisdiksi lain termasuk Bahrain, Pakistan, dan Uni Emirat Arab (UEA) menjadikan model tata kelola Syariah milik Malaysia sebagai acuan penyusunan kerangka tata kelola Syariah (Parker, 2017).

Berdasarkan latar belakang tersebut, penelitian ini dilakukan dengan tujuan untuk mengevaluasi infrastruktur tata kelola Syariah di Indonesia, khususnya pada fungsi ex 
post DPS yaitu Shariah review yang diungkap pada laporan tahunan perbankan Syariah. Eksplorasi infrastruktur fokus pada prosedur, proses, dan mekanisme setiap struktur yang terlibat dalam fungsi Shariah review. Untuk selanjutnya dilakukan analisis kemungkinan adopsi SGF milik Malaysia yang didasarkan pada kondisi infrastruktur tata kelola Syariah di perbankan Syariah di Indonesia dan beberapa langkah untuk menjalankannya.

\section{Kerangka Tata Kelola Syariah (Shariah Governance)}

Salah satu versi kerangka tata kelola perusahaan Islami diuraikan olehAbdul Rahman (1998) dalam ISRA (2015), yang menyajikan sebuah kerangka yang mengintegrasikan Syariah dan ajaran-ajaran moral Islam. Uraian tersebut menitikberatkan lembaga syura, hisbah, dan audit religi sebagai komponen-komponen utama sebuah kerangka tata kelola perusahaan. Lembaga syura - yang terdiri dari pihak manajemen, dewan direksi, para pemegang saham, para karyawan, para pelanggan, dan pihak-pihak berkepentingan yang lain - dapat memastikan efektivitas pengambilan keputusan perusahaan manapun. Di sisi lain, lembaga hisbah berperan memonitor perusahaan-perusahaan pada aspek regulasi dan aspek moral. Para auditor religius atau badan - dewan Syariah mengeluarkan putusan-putusan hukum dan menyediakan saran atau nasehat terkait perkiraan-perkiraan area audit, supervisi serta pengawasan audit.

Kerangka tata kelola Syariah meliputi kepatuhan terhadap Syariah aspek perkiraan (ex ante) dan aspek aktual (ex post), yakni aspek perkiraan merujuk pada penerbitan putusan-putusan Syariah dan penyebarluasan informasi terkait Syariah, sedangkan aspek aktual merujuk pada proses Shariah review internal periodik dan Shariah review internal tahunan. Komponen paling esensial dari tata kelola perusahaan Islami adalah keberadaan DPS. DPS berperan sentral dalam memastikan keabsahan produk-produk berdasarkan prinsip-prinsip Syariah. Dalam menjalankan tugas ini, DPS membutuhkan suatu kerangka dan struktur yang jelas untuk memastikan keefektifan DPS. Berdasarkan kondisi ini, maka segala bentuk pengaturan yang secara formal disusun akan diarahkan untuk membantu DPS dalam melakukan upaya monitoring, pengawasan dan pengendalian untuk memastikan kepatuhan Syariah yang merupakan bagian dari sistem tata kelola Syariah (Shariah Governance).

\section{Konsep Review Syariah}

Shariah Governance Framework BNM pada paragraf 2 mendefinisikan "Shariah review" sebagai "fungsi Shariah review yang merujuk pada penilaian regular tentang kepatuhan aktivitas-aktivitas dan operasi-operasi Lembaga Keuangan Syariah (LKS) tersebut terhadap prinsip-prinsip Syariah, dengan tujuan memastikan bahwa aktivitasaktivitas dan operasi-operasi tersebut yang dijalankan oleh LKS tidak bertentangan dengan prinsip-prinsip Syariah". Dengan demikian, Shariah review itu spesifik terkait kepatuhan terhadap Syariah, dalam kaitannya dengan operasi-operasi bisnis LKS tersebut secara keseluruhan dan tidak mencakup seluruh laporan keuangan (paragraf 7.3 - paragraf 7.5). Jaminan kepatuhan Syariah atas keseluruhan aktivitas perbankan menjadi fungsi utama DPS. Prinsip kehati-hatian menjadi acuan penerapan visi tata kelola Syariah pada perbankan Syariah (Maradita, 2014).

Tidak seperti audit Syariah, Shariah review harus dijalankan oleh "para staf Syariah berkualifikasi", yang didefinisikan oleh BNM di dalam paragraf 7.3 sebagai "staf yang 
memegang sedikitnya gelar cendekiawan Syariah, yang mana mencakup studi Usul AlFiqh (asal usul hukum Islam) dan Fiqh Mu'amalat (hukum transaksi/hukum dagang Islam)." Sehingga terlihat perbedaan antara "audit" dan "peninjauan" menurut BNM adalah bahwa "audit" merupakan penilaian "independen" dan "periodik"; sedangkan terkait "peninjauan", tidak ada syarat independensi, tetapi perlu ada "penilaian regular" (yang berarti, lebih kerap dilakukan ketimbang audit) dan penilaian ini adalah tentang "kepatuhan terhadap Syariah" dalam kaitannya dengan aktivitas dan operasional yang dijalankan oleh LKS tersebut.

\section{Shariah Governance Framework Bank Negara Malaysia}

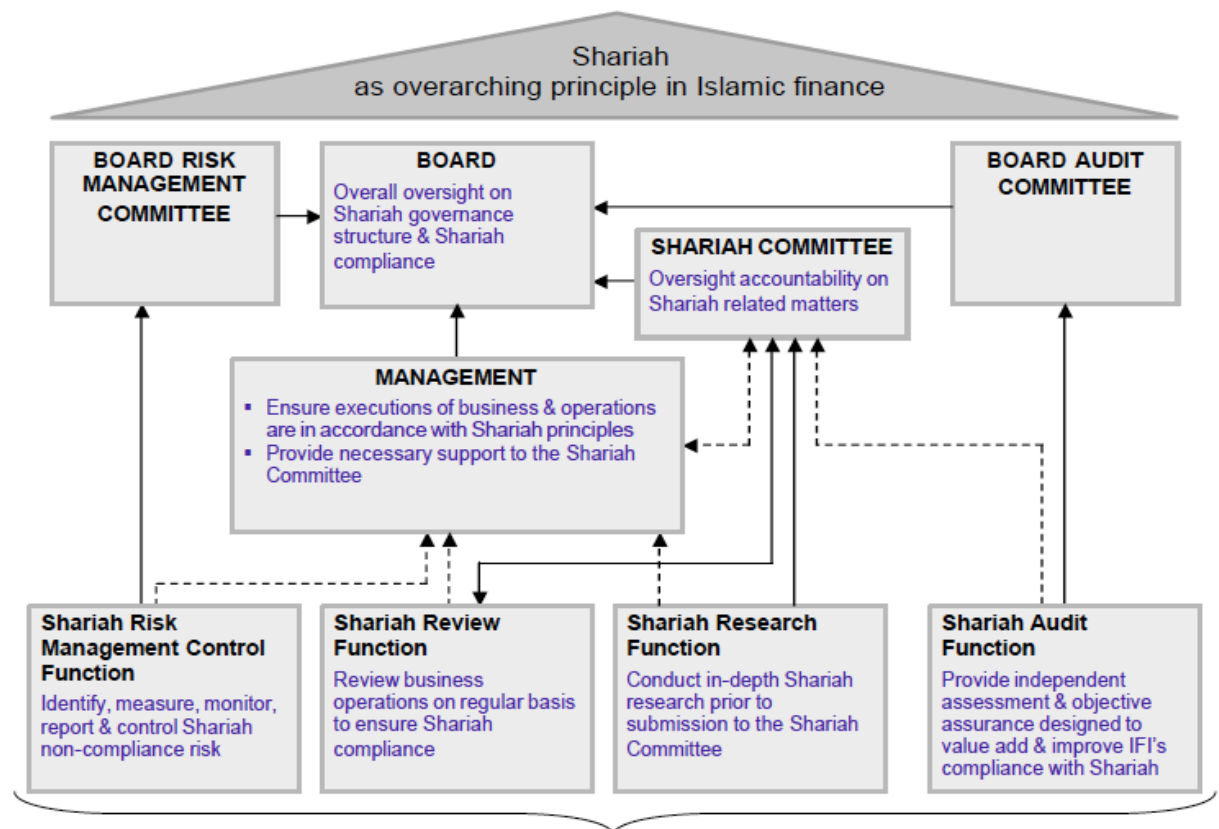

Shariah Compliance and Research Functions

Gambar 1. Shariah Governance Framework BNM (2011)

Kerangka tata kelola Syariah yang sehat dan kuat direfleksikan oleh dewan dan manajemen yang efektif dan bertanggungjawab, komite Syariah independen yang kompeten dan bertanggungjawab, didukung oleh kapasitas penelitian internal Syariah yang kuat, dan dimonitor melalui Shariah review yang aktif, serta audit Syariah dan departemen manajemen risiko Syariah (BNM, 2011).

\section{METODE PENELITIAN}

Penelitian ini menggunakan pendekatan deskriptif kualitatif untuk menjabarkan gambaran umum mengenai praktik Shariah review fase ex post pada perbankan Syariah di Indonesia dan mendeskripsikan persepsi para ahli mengenai kemungkinan adopsi Shariah Governance Framework BNM. Menggunakan 3 sampel penelitian, yaitu Bank Syariah Mandiri (BSM), Unit Usaha Syariah Bank Pembangunan Daerah Daerah 
Istimewa Yogyakarta (UUS BPD DIY), dan Bank Perkreditan Rakyat Syariah (BPRS) Bhakti Sumekar untuk mengeksplorasi infrastruktur Shariah review yang diungkap pada laporan tahunannya. Lebih lanjut, metode wawancara mendalam digunakan untuk mendapatkan persepsi para ahli mengenai kemungkinan adopsi SGF BNM berdasarkan kondisi infrastruktur tata kelola Syariah di Indonesia. Narasumber merupakan akademisi dengan kepakaran terkait Governance yang memahami tata kelola Syariah di Indonesia dan Malaysia.

\section{HASIL DAN PEMBAHASAN}

\section{Mekanisme Fungsi Shariah review oleh DPS di Bank Syariah Mandiri}

Pengungkapan mengenai pelaksanaan tugas dan tanggung jawab DPS terletak pada laporan tahunan pada sub bagian tata kelola perusahaan. Koordinasi antara DPS dengan unit kerja Internal Audit serta Satuan Kerja Kepatuhan (Compliance) dilakukan guna menunjang proses Shariah review atas penerapan fatwa DSN-MUI pada operasional BSM. Koordinasi tersebut membantu DPS dalam mengetahui kualitas pelaksanaan pemenuhan prinsip Syariah, yaitu melaksanakan pengumpulan data dan informasi cabang yang telah ditentukan untuk dilakukan uji petik. Rapat internal DPS dilakukan secara berkala pada awal tahun guna menentukan sampel uji petik. Untuk menunjang kelengkapan data sampel, Internal Audit \& Anti Fraud Group (IAG) masing-masing Kantor Cabang yang akan diuji petik menyerahkan laporan hasil temuannya kepada DPS.

Bersamaan dengan proses uji petik, DPS berdialog dengan pimpinan dan karyawan cabang untuk menganalisa kemungkinan timbulnya kendala bisnis dan operasional yang bergesekan dengan aspek Syariah. Lebih lanjut, diadakan Forum Klinik Syariah, yaitu pemberian materi “Akad dan Produk Perbankan Syariah". Hal tersebut bertujuan untuk menekankan dan menguatkan kembali pemahaman struktur kantor cabang berkaitan dengan skema produk dan jasa perbankan Syariah.

Hasil pengawasan dengan metode uji petik yang telah dilakukan kemudian dilaporkan kepada Direksi dan Dewan Komisaris. Pelaporan secara berkala tiap enam bulan tersebut berisikan dokumentasi aktivitas DPS. Salah satunya mengungkapkan bentuk pengawasan yang telah dilakukan yaitu; analisis laporan hasil Audit Internal, penetapan dan pemeriksaan jumlah uji petik, serta review SOP terkait aspek Syariah.

Pengawalan Shariah review yang dilakukan oleh DPS menjadi tanggungjawab Satuan Kerja Kepatuhan. Fungsi tersebut bertanggungjawab atas terlaksananya prosedur uji petik oleh DPS hingga memastikan tersusunnya laporan hasil pengawasan DPS dan penyampaiannya kepada OJK secara periodik (semester).

\section{Mekanisme Fungsi Shariah review oleh DPS di Unit Usaha Syariah BPD DIY}

Pengungkapan pelaksanaan tata kelola yang ditampilkan pada laporan tahunan UUS BPD DIY tidak menyediakan informasi terkait bagan struktur organisasi tata kelolanya. Namun, terdapat penjelasan secara singkat bahwa struktur organisasi tata kelola Unit Usaha Syariah pada BPD DIY terdiri atas dua komponen yaitu Direktur Unit Usaha Syariah dan Dewan Pengawas Syariah. Direktur Unit Usaha Syariah bertanggung jawab penuh terhadap pelaksanaan prinsip syariah di Bank BPD DIY. Guna 
mengoptimalkan peran dan fungsinya, Direktur Unit Usaha Syariah dibantu oleh DPS yang memiliki peran sebagai pengawas dan penasihat dalam aspek kepatuhan Syariah pada kegiatan Unit Usaha Syariah.

Direktur UUS bertanggungjawab dalam menyediakan data dan informasi terkait dengan pemenuhan prinsip Syariah yang akurat, relevan, dan tepat waktu kepada DPS di antaranya adalah data perkembangan kinerja UUS per bulan. Rekomendasi DPS kepada Direktur UUS dalam bentuk notulen rapat wajib ditindaklanjuti melalui koordinasi antar internal UUS maupun penyusunan kebijakan.

Risalah rapat yang berisikan tanggal dan materi rapat menjadi sarana akuntabilitas DPS BPD DIY dalam melaksanakan fungsi review Syariah. Materi rapat menjabarkan tema pokok yang dibahas pada saat rapat dilaksanakan. Dalam 1 tahun, 13 kali rapat dilakukan oleh internal DPS, dan 1 kali pertemuan dilakukan oleh DPS bersama Direksi. Lebih lanjut, self assessment atas pelaksanaan GCG menduduki peringkat 1 yang artinya sangat baik. Termasuk di dalamnya penilaian mengenai tugas dan tanggungjawab DPS, efektivitas rapat, dan transparansi DPS berpredikat sangat baik.

\section{Mekanisme Fungsi Shariah review oleh DPS di BPR Syariah Bhakti Sumekar}

Hasil Shariah review yang dilakukan oleh DPS BPRS Bhakti Sumekar diungkap pada Laporan Dewan Pengawas Syariah. Diungkap beberapa rekomendasi berdasarkan pengawasan Syariah yang telah dilakukan, salah satunya yaitu alokasi dana qardhul hasan yang harus dipisah dari dana ZIS. Rekomendasi lain yaitu perlunya meningkatkan pengawasan intens dari internal bank dalam realisasi produk pembiayaan, dimana ditemui ketidaksesuaian antara tujuan dengan realisasi pembiayaan, khususnya dalam akad murabahah.

Selain berkewajiban memberikan opini Syariah, DPS juga berperan dalam memberikan saran dan arahan agar operasional bank tetap dalam kepatuhan Syariah. Dalam hal ini, diungkap bahwa DPS menyarankan dan sangat mengharapkan produkproduk yang ada di BPRS Bhakti Sumekar lebih banyak menggunakan akad dengan prinsip bagi hasil yaitu musyarakah dan mudharabah. Meskipun akad berbasis jual beli seperti murabahah memberikan tingkat return yang pasti bagi BPRS. DPS juga menekankan fokus perhatian BPRS Bhakti Sumekar adalah falah-oriented, tidak hanya profit-oriented.

\section{Urgensi Penyusunan Framework dan Kemungkinan Adopsi SGF BNM}

Setelah diberlakukannya Shariah Governance Framework BNM untuk lembaga keuangan Syariah di Malaysia, khususnya pada fungsi Shariah audit ditemukan bahwa dewan Syariah lebih mudah dalam mengidentifikasi risiko ketidakpatuhan Syariah yang dihadapi perbankan Syariah dalam tahap penerapan fatwa (Shafii, Abidin, Salleh, Jusoff, \& Kasim, 2013).

Metode wawancara mendalam dilakukan guna mendapatkan persepsi narasumber mengenai kemungkinan adopsi Shariah Governance Framework BNM berdasarkan kondisi infrastruktur tata kelola Syariah di Indonesia. Berikut pemaparan hasil wawancara mendalam yang disajikan secara singkat berdasarkan kata kunci yang dianggap dapat mewakili keseluruhan ide. 


\section{Definisi Tata Kelola Syariah dan Konsep Akuntabilitas Laporan Tata Kelola Syariah}

Tata kelola Syariah merupakan additional governance yang harus ada di Lembaga Keuangan Syariah. Tata kelola Syariah merupakan prosedur, struktur, dan mekanisme untuk meyakinkan publik bahwa produk dan aktivitas di dalam LKS sesuai dengan prinsip Syariah. Sehingga keberadaan tata kelola Syariah adalah untuk memastikan kesesuaian produk perbankan, aktivitas dan operasionalnya dengan fatwa DSN-MUI. Laporan tata kelola Syariah yang ada pada laporan tahunan bank Syariah merupakan sarana akuntabilitas, salah satunya DPS dalam mengungkap kegiatan Shariah review terhadap penerapan fatwa DSN MUI pada operasional bank. Akuntabilitas meliputi kepada siapa laporan ditujukan, yaitu kepada stakeholders, kemudian konteks pelaporan, yaitu mekanisme dalam melakukan pengawasan, serta hal-hal apa saja yang harus diungkapkan. Fungsi tata kelola adalah memastikan bahwa akuntabilitas dijalankan sesuai aturan yang ada. Lebih lanjut, tata kelola tidak akan bisa efektif dijalankan tanpa adanya akuntabilitas.

\section{Nilai Penting Kerangka Tata Kelola Syariah (Shariah Governance)}

Framework tata kelola Syariah sangat penting untuk dimiliki, karena berfungsi sebagai panduan untuk setiap komponen tata kelola Syariah. Dengan adanya framework dapat mempermudah dalam mengevaluasi sejauh mana efektivitas dan proses Shariah Governance berjalan untuk mencegah terjadinya risiko ketidakpatuhan Syariah. Memiliki framework memberikan kepastian mengenai eksistensi struktur dan hubungan yang jelas antar struktur tata kelola Syariah. Shariah Governance di perbankan Syariah direpresentasikan dengan adanya DPS yang mampu mempengaruhi kinerja perbankan Syariah karena eksistensi dan optimalisasi peran pengawasan (Mollah \& Zaman, 2015). Hal ini juga diungkapkan oleh Nomran, Haron, dan Hassan (2018) yang mengungkapkan bahwa kinerja perbankan Syariah salah satunya dipengaruhi oleh karakteristik DPS yang berkaitan dengan ukuran DPS, reputasi, dan pengalamannya. Hal ini tentu menguatkan pentingnya Shariah Governance.

\section{Kemungkinan Adopsi Shariah Governance Framework Bank Negara Malaysia di Indonesia}

Pada mekanisme tata kelola Syariah, DPS merupakan elemen kunci yang berperan dalam memberikan shariah assurance. Sejak kemunculan bank Muamalat pada tahun 1992 yang menjadi awal mula pertumbuhan keuangan Syariah di Indonesia, hingga kini peraturan yang mengatur mengenai DPS hanya ada pada UU Nomor 21 tahun 2008 yang mensyaratkan perbankan Syariah untuk memiliki DPS. Segala yang mengatur DPS, seperti mekanisme kerja, kompetensi, pengangkatan dan pemberhentian, dan lain sebagainya diatur dalam Peraturan Bank Indonesia dan Surat Edaran Bank Indonesia, yang dari sisi kekuatan hukum sangat lemah. Lain halnya dengan Malaysia, segala yang mengatur mengenai DPS berbentuk Undang-Undang, apabila dilihat dari perspektif hukum sangat kuat kedudukannya.

Begitu banyak peraturan di Indonesia yang mengatur mengenai governance, dalam konteks yang berkembang dari masa ke masa. Namun belum ada framework seperti yang diterbitkan oleh Bank Negara Malaysia. Untuk penyusunan framework di Indonesia 
sebenarnya bisa dimulai dengan melakukan mapping peraturan-peraturan yang sudah ada. Mapping didasarkan pada hubungan dan wewenang organisasi yang terkait dengan tata kelola Syariah, misalnya OJK, DSN-MUI, DPS, dan eksternal auditor. Dari 4 pihak tersebut bisa disusun sebagai satu framework yang berbeda dengan Malaysia.

Bila mengacu pada SGF BNM, terdapat beberapa karakteristik regulasi di Indonesia yang berbeda dengan Malaysia. Misalnya mengenai proses pengembangan produk, pada SGF BNM memiliki fungsi Shariah research yang berfungsi melakukan evaluasi terhadap kemungkinan produk baru. Secara substansi, Shariah research dapat diaplikasikan pada praktik di Indonesia walaupun secara formal belum dibentuk dalam unit khusus. Manajemen dapat mengajukan usulan pengembangan produk berdasarkan kebutuhan pasar dan disesuaikan dengan Fatwa DSN-MUI. Manajemen dalam hal ini dapat menjalankan substansi fungsi Shariah research dalam melakukan inovasi produk dengan berkonsultasi ke DPS. Disisi lain, Shariah audit dilakukan oleh internal auditor dan Shariah review dilakukan oleh DPS dalam kerangka SGF BNM. Sedang di Indonesia, hal yang mengacu pada pelaksanaan Shariah audit dan Shariah review menjadi tanggungjawab DPS.

\section{Kualitas Pengungkapan Proses Shariah Review pada Laporan Tahunan Perbankan Syariah di Indonesia}

Pengungkapan governance pada laporan tahunan sifatnya voluntary disclosure, pada pedoman Standar Akuntansi Keuangan (SAK) tidak mengatur hal-hal apa saja yang harus dilaporkan. Sehingga belum ada standar ukuran sejauh mana laporan kegiatan DPS harus diungkap pada laporan keuangan ataupun internal bank Syariah. Sejauh yang dipahami oleh narasumber, pengungkapan Shariah review oleh DPS masih bersifat normatif. Menyatakan bahwa DPS sudah berusaha untuk meyakinkan manajemen untuk menjunjung tinggi implementasi Syariah pada setiap aktivitasnya. Namun, ditemukan oleh narasumber bahwa ada beberapa bank Syariah pada skala daerah yang mengungkapkan substansi kegiatan Shariah review oleh DPS. Beberapa bank tersebut mengungkap waktu, risalah, dan hasil rapat yang dilakukan oleh DPS, hingga nominal remunerasi DPS. Hal ini berfungsi untuk menunjukkan bahwa posisi DPS adalah independen, kredibel dan transparan dalam mengungkapkan aktivitasnya. Lebih lanjut mengenai opini DPS, berdasarkan studi yang dilakukan narasumber, dinyatakan oleh DPS bahwa opini yang dikeluarkan di-review oleh OJK. Dimana secara periodik setiap 6 bulan sekali DPS menyerahkan laporan kinerjanya kepada OJK.

Muneeza dan Hassan (2014) menjelaskan bahwa frekuensi pertemuan DPS dengan manajemen tentu memiliki dampak terhadap tingkat kepatuhan Syariah. DPS dapat mengusulkan rapat yang dianggap penting baik secara internal antar anggota DPS maupun rapat yang melibatkan manajemen dan pemegang saham. Namun demikian, Muneeza dan Hassan (2014) masih menemukan kelemahan eksistensi DPS yang tergantung dengan permintaan pertemuan yang dilakukan oleh manajemen untuk sekedar mengkonsultasikan beberapa hal yang dianggap penting dan baru sebatas memenuhi ketentuan minimal frekuensi rapat yang diatur oleh regulator. Oleh karena itu, perlu ada mekanisme yang mampu memberikan ruang untuk DPS agar memiliki peran lebih dalam mempengaruhi kinerja perbankan Syariah yang tidak sekedar memenuhi kriteria minimal saja sehingga pengungkapan di laporan tahunan bisa semakin baik. 


\section{Kemungkinan Penerapan Fungsi Shariah Audit, Shariah Review, Shariah Risk Management, dan Shariah Research pada Perbankan Syariah di Indonesia}

Praktik pengawasan Syariah di perbankan Syariah di Indonesia tidak dibagi menjadi beberapa fungsi seperti pada SGF BNM. Hal tersebut salah satunya disebabkan terbatasnya SDM yang memiliki dual competency yaitu hukum Syariah dan keuangan. Namun ketiadaan empat fungsi seperti di SGF BNM tersebut bukan berarti bahwa bank Syariah di Indonesia tidak menjalankan fungsi tersebut. Misalnya mengenai manajemen risiko, UU perbankan Indonesia mengharuskan setiap perbankan untuk memiliki fungsi manajemen risiko yang bertugas dalam mengidentifikasi, melakukan penilaian, melakukan mitigasi atas risiko dan melakukan pelaporan. Namun tidak diketahui secara pasti apakah perbankan syariah juga memiliki fungsi untuk mengantisipasi risiko-risiko yang berkaitan dengan ketidakpatuhan Syariah. Kemudian untuk Shariah research, pada praktiknya manajemen bank mengajukan produk-produk yang belum ada fatwanya. Sehingga bisa dipahami bahwa tidak ada lembaga mengenai Shariah research, namun perbankan secara fungsional melakukan hal tersebut. Lebih lanjut, fungsi Shariah review dan Shariah audit di Indonesia berada dalam lingkup tanggungjawab DPS.

\section{Analisis Komparatif Shariah review BSM, UUS BPD DIY, BPRS Bhakti Sumekar}

Peran dan tanggungjawab DPS terbagi menjadi 2 lingkup, yaitu ex ante (sebelum terjadi transaksi) dan ex post (setelah terjadi transaksi). Pada praktiknya, Hasan (2014) menyatakan bahwa beberapa dewan Syariah tidak melakukan fungsi Shariah review, hanya fokus pada fungsi-fungsi ex ante. Bahkan, mereka menandatangani deklarasi ketaatan Syariah pada laporan tahunan tanpa melakukan proses Shariah review yang semestinya.

Analisis pengungkapan pada laporan tahunan BSM, UUS BPD DIY, BPRS Bhakti Sumekar dilakukan untuk mengetahui infrastruktur tata kelola pada Shariah review yang terdiri atas prosedur, proses, dan mekanisme yang dilakukan oleh DPS. Lebih lanjut didapatkan informasi seperti yang tertera pada tabel berikut:

Tabel 1. Aspek Shariah review Perbankan Syariah

\begin{tabular}{llll}
\hline Indikator Pengungkapan & Bank Syariah Mandiri & $\begin{array}{l}\text { Unit Usaha } \\
\text { Syariah BPD } \\
\text { DIY }\end{array}$ & $\begin{array}{c}\text { BPR Syariah } \\
\text { Bhakti Sumekar }\end{array}$ \\
\hline Unit koordinasi & $\begin{array}{l}\text { Internal Audit dan } \\
\text { Satuan Kerja Kepatuhan } \\
\text { (Compliance) }\end{array}$ & $\begin{array}{l}\text { Direktur } \\
\text { Unit Usaha } \\
\text { Syariah }\end{array}$ & Tidak Diungkap \\
Metode & Uji Petik & $\begin{array}{l}\text { Tidak } \\
\text { Diungkap }\end{array}$ & Tidak Diungkap \\
Jumlah Anggota DPS & 3 & 2 & 2 \\
Frekuensi Rapat & 9 & 14 & Tidak Diungkap \\
Risalah Rapat & Diungkap & Diungkap & Tidak Diungkap \\
Saran dan Rekomendasi & Diungkap & Diungkap & Diungkap \\
\hline
\end{tabular}


Berdasarkan tabel 1, dapat disimpulkan bahwa pengungkapan Shariah review oleh BSM merupakan yang terlengkap dibandingkan dengan dua bank Syariah lainnya. Hal tersebut didukung oleh penelitian Adiono dan Sholihin (2014) ditemukan bahwa BSM merupakan salah satu bank Syariah dengan nilai pengungkapan governance tertinggi. Pada laporan tata kelola terdapat bagan struktur tata kelola yang menjelaskan hubungan tiap struktur. Melalui gambar 2 dapat diketahui bahwa dalam melakukan review Syariah, DPS didukung oleh beberapa fungsi, khususnya unit Satuan Kerja Audit Internal (SKAI) yang memberikan hasil audit internal kepada DPS, serta unit Compliance (Satuan Kerja Kepatuhan) yang bertanggungjawab atas pelaksanaan uji petik oleh DPS. Hubungan koordinasi DPS dan SKAI serta unit Compliance digambarkan pada struktur tata kelola Syariah seperti pada gambar 2. Ketersediaan struktur tersebut memberikan pemahaman yang jelas dan tegas atas wewenang, tugas, dan hubungan antar struktur yang terlibat dalam proses review Syariah. Namun, pelaksanaan rapat oleh internal DPS hanya sejumlah 9 pertemuan dalam setahun, jumlah tersebut jauh lebih sedikit dibandingkan dengan UUS BPD DIY yang menyelenggarakan 14 pertemuan dalam satu tahun. Dinyatakan oleh Grassa (2013), bahwa ketiadaan persyaratan wajib mengenai jumlah pertemuan yang harus diselenggarakan dapat menjadi sinyal buruk atas efisiensi DPS. Diperlukan standar jumlah minimum frekuensi rapat untuk DPS yang dilakukan secara periodik.

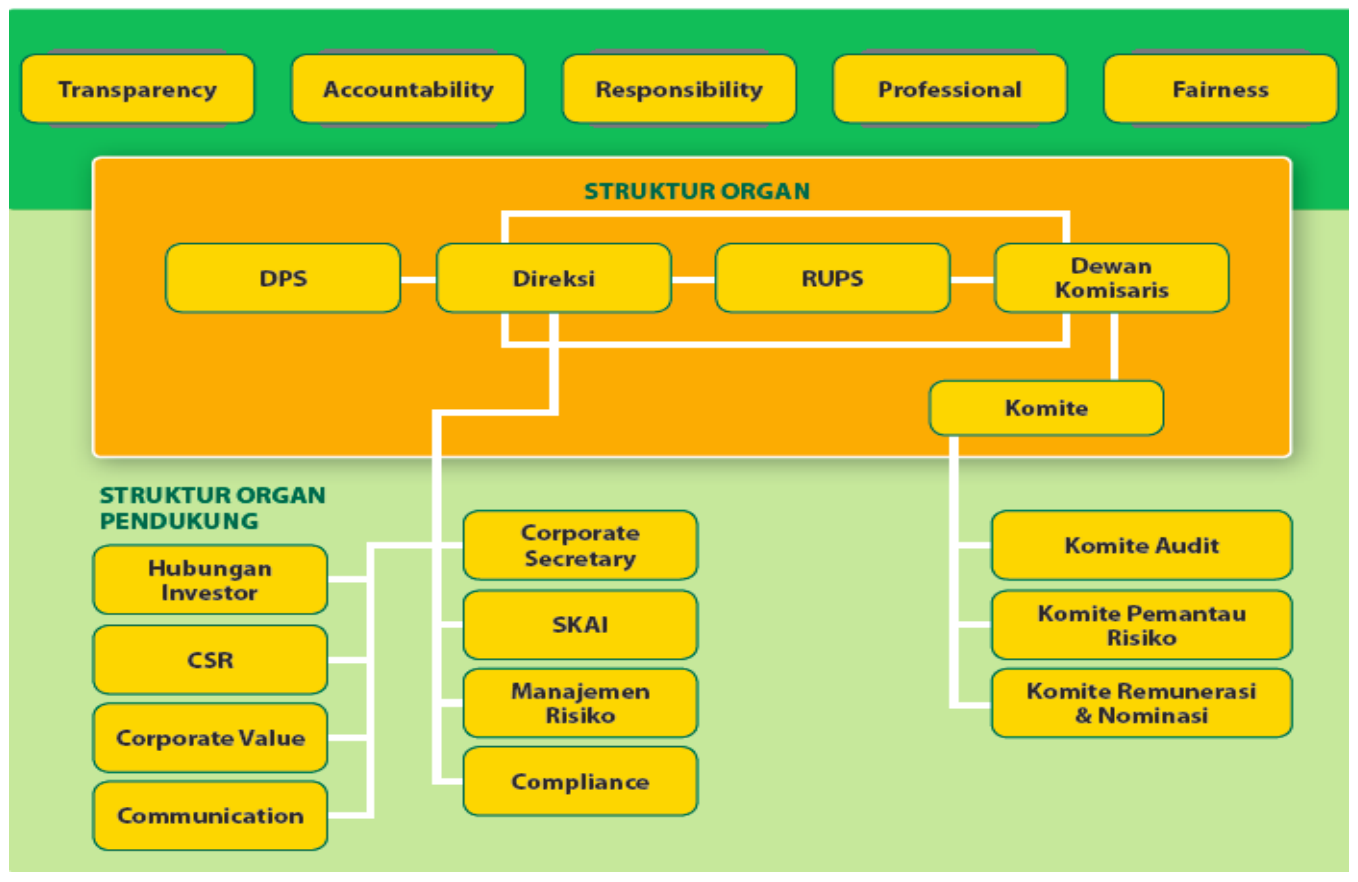

Gambar 2. Struktur Governance BSM (2017)

Meskipun pengungkapan kedua bank lainnya yaitu UUS BPD DIY dan BPRS Bhakti Sumekar kurang komprehensif bila dibandingkan dengan BSM, pengungkapan 
Shariah review kedua bank tersebut memiliki nilai lebih yang tidak ada pada BSM. Pada UUS BPD DIY, risalah rapat diungkap secara detail dan terperinci mulai dari tanggal dilaksanakannya rapat, agenda rapat, hingga rekomendasi oleh DPS seperti dapat dilihat pada gambar 3 berikut. Namun, tidak diungkap mengenai metode yang digunakan dalam melakukan Shariah review terhadap kantor cabang seperti yang diungkap pada BSM, yaitu menggunakan uji petik.

\begin{tabular}{|c|c|c|}
\hline No. & Tanggal / Date & Materi Rapat / Meeting Agenda \\
\hline 1 & $\begin{array}{l}25 \text { Januari } 2017 \text { / January } \\
25,2017\end{array}$ & $\begin{array}{l}\text { Pembahasan Tentang Penyampaian Kinerja Tahun } 2016 \text { dan RBB Tahun } 2017 \text { / Discussion of } \\
\text { Performance in } 2016 \text { and } 2017 \text { RBB }\end{array}$ \\
\hline 2 & $\begin{array}{l}08 \text { Februari } 2017 \text { / February } \\
08,2017\end{array}$ & $\begin{array}{l}\text { Pembahasan Tentang Laporan DPS Semester II Tahun } 2016 \text { / Discussion of DPS Report } \\
\text { Semester II of } 2016\end{array}$ \\
\hline 3 & $\begin{array}{l}29 \text { Maret } 2017 / \text { March 29, } \\
2017\end{array}$ & $\begin{array}{l}\text { Pembahasan Tentang Pembiayaan Sindikasi kepada PT. PLN (Persero) dan PT. Pemalang } \\
\text { Batang Toll Road (PBTR) / Discussion of Syndicated Financing to PT PLN (Persero) and PT } \\
\text { Pemalang Batang Toll Road (PBTR) }\end{array}$ \\
\hline 4 & $\begin{array}{l}05 \text { April 2017 / April 05, } \\
2017\end{array}$ & $\begin{array}{l}\text { Pembahasan Tentang Template Analisa Pembiayaan untuk Usaha/Komersial dan atau } \\
\text { Konsumsi / Discussion of Financing Analysis Template for Business/Commercial and or } \\
\text { Consumption }\end{array}$ \\
\hline 5 & 10 Mei 2017 / May 10, 2017 & $\begin{array}{l}\text { Pembahasan Tentang Pemberian Pembiayaan Investasi Kepada Universitas Ahmad Dahlan } \\
\text { dan Sindikasi kepada PT. Bandarudara Internasional Jawa Barat (PT.BIB) / Discussion } \\
\text { on Providing Investment Financing to Ahmad Dahlan University and Syndicated to PT } \\
\text { Bandarudara Internasional Jawa Barat (PT BIB). }\end{array}$ \\
\hline 6 & $\begin{array}{l}07 \text { Juni } 2017 \text { / June } 07 \text {, } \\
2017\end{array}$ & $\begin{array}{l}\text { Pembahasan Tentang Pemberian Pembiayaan kepada Yayasan Salman Al Farisi Yogyakarta / } \\
\text { Discussion on Providing Financing to Foundation of Salman Al Farisi Yogyakarta }\end{array}$ \\
\hline 7 & 05 Juli 2017 / July 05, 2017 & $\begin{array}{l}\text { Pembahasan Tentang Ketentuan Pembiayaan dengan Akad Musyarakah Mutanaqishah (MMQ) } \\
\text { / Discussion of Financing Provision with Akad Musyarakah Mutanaqishah (MMQ) }\end{array}$ \\
\hline 8 & $\begin{array}{l}09 \text { Agustus } 2017 \text { / August } \\
\text { 09, } 2017\end{array}$ & $\begin{array}{l}\text { Pembahasan Tentang Penilaian Aspek Syariah Kerjasama Dengan SD Muhammadiyah Sagan } \\
\text { dan SMA Muhammadiyah } 7 \text { / Discussion of Sharia Cooperation Aspect Assessment with SD } \\
\text { Muhammadiyah Sagan and SMA Muhammadiyah } 7\end{array}$ \\
\hline 9 & $\begin{array}{l}20 \text { September } 2017 / \\
\text { September } 20,2017\end{array}$ & $\begin{array}{l}\text { Pembahasan Tentang Penilaian Aspek Syariah Kerjasama Pengelolaan Payroll Gaji SD } \\
\text { Muhammadiyah Kadisoka / Discussion of Sharia Cooperation Aspect Assessment of Payroll } \\
\text { Management SD Muhammadiyah Kadisoka }\end{array}$ \\
\hline 10 & $\begin{array}{l}18 \text { Oktober } 2017 / \text { October } \\
18,2017\end{array}$ & $\begin{array}{l}\text { Pembahasan Tentang Surat Edaran DSN MUI terkait Sertifikasi Kompetensi bagi DPS / } \\
\text { Discussion on Circular Letter of DSN MUI related to DPS Competency Certification }\end{array}$ \\
\hline 11 & $\begin{array}{l}08 \text { November } 2017 / \\
\text { November } 08,2017\end{array}$ & $\begin{array}{l}\text { Pembahasan Tentang Laporan Pembiayaan Bermasalah dan Tindak Lanjut Penyelesaiannya / } \\
\text { Discussion of Non-Performing Financing Report and Its Settlement }\end{array}$ \\
\hline 12 & $\begin{array}{l}13 \text { Desember } 2017 / \\
\text { December } 13,2017\end{array}$ & $\begin{array}{l}\text { Pembahasan Tentang Penilaian Aspek Syariah kepada PT. Khalifah Wijaya Putra dan } \\
\text { Pertemuan antara DPS dengan Direktur Pemasaran dan Usaha Syariah / Discussion of Sharia } \\
\text { Aspect Assessment to PT Khalifah Wijaya Putra and Meeting between DPS and Marketing and } \\
\text { Sharia Business Director }\end{array}$ \\
\hline 13 & $\begin{array}{l}20 \text { Desember } 2017 / \\
\text { December } 20,2017\end{array}$ & $\begin{array}{l}\text { Pembahasan Tentang Permohonan Bank BPD DIY Syariah untuk Menjadi Bank Penerima } \\
\text { Setoran Biaya Penyelenggaran Ibadah Haji (BPS BPIH) / Discussion of Application of Bank BPD } \\
\text { DIY Sharia to become Bank Recipients of Savings for Costs of Hajj (BPS BPIH) }\end{array}$ \\
\hline 14 & $\begin{array}{l}28 \text { Desember } 2017 / \\
\text { December } 28,2017\end{array}$ & $\begin{array}{l}\text { Pembahasan Tentang Penilaian Aspek Syariah Pembiayaan kepada Rumah Sakit Bedah (RSB) } \\
\text { Soedirman Yogyakarta / Discussion of Assessment of Sharia Financing Asspect to Surgery } \\
\text { Hospital (RSB) Soedirman, Yogyakarta }\end{array}$ \\
\hline
\end{tabular}

\section{Gambar 3. Risalah Rapat UUS BPD DIY (2017)}

Kemudian pada BPRS Bhakti Sumekar, tidak diungkap mengenai mekanisme tata kelola bank Syariah, sehingga tidak ada informasi yang didapat mengenai proses pelaksanaan Shariah review oleh DPS. Namun apabila melihat struktur organisasi BPRS Bhakti Sumekar pada gambar 4, bisa dilihat adanya alur hubungan antara DPS dengan Satuan Kerja Audit Internal (SKAI) dan Divisi Kepatuhan Syariah. Bila dianalogikan dengan struktur Governance yang ada pada BSM, kedua fungsi tersebut yang menunjang pelaksanaan Shariah review oleh DPS. Lebih lanjut mengenai opini DPS BPRS Bhakti Sumekar, pelaporannya tidak terkesan normatif seperti pada kedua bank Syariah lainnya. Secara substansi diungkap oleh DPS mengenai tanggungjawabnya, risiko ketidakpatuhan Syariah yang mungkin dihadapi apabila BPRS Bhakti Sumekar 
condong pada pembiayaan murabahah. Dinyatakan bahwa DPS menyarankan dan sangat mengharapkan BPRS Bhakti Sumekar lebih banyak menggunakan akad yang berbasis natural uncertainty contracts (akad dengan prinsip bagi hasil, misal musyarakah dan mudharabah), tidak lagi condong pada akad yang berbasis natural certainty contracts (akad dengan prinsip jual beli, misal murabahah). Agar apa yang menjadi visi BPRS Bhakti Sumekar tercermin dalam produk yang dimiliki, yaitu mitra dalam bermuamalah. DPS juga mengingatkan kepada manajemen BPRS Bhakti Sumekar bahwa yang harus menjadi fokus perhatian bank Syariah tidak hanya profit-oriented namun juga falahoriented.

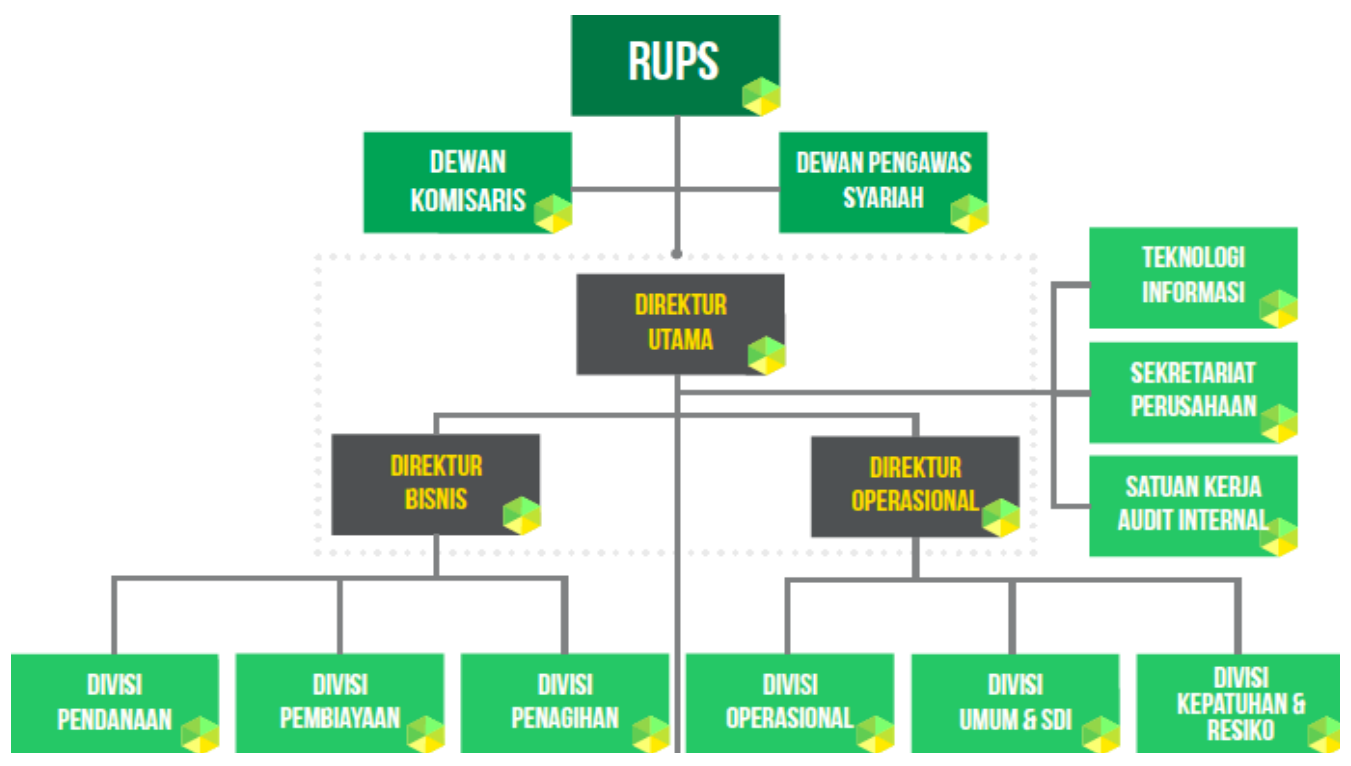

Gambar 4. Struktur Organisasi BPR Syariah Bhakti Sumekar (2017)

\section{Analisis Deskriptif Kemungkinan Adopsi Shariah Governance Framework BNM}

Berdasarkan pada analisis pengungkapan fungsi ex post DPS yaitu Shariah review pada laporan tahunan, diketahui bahwa praktik tata kelola bank Syariah di Indonesia memiliki regulasi, struktur organisasi, proses, dan fungsi yang berbeda dengan Malaysia. Sehingga dinyatakan oleh narasumber bahwa SGF BNM kurang sesuai untuk diterapkan di Indonesia. Peraturan Governance di Indonesia diatur dalam Peraturan Bank Indonesia dan Surat Edaran Bank Indonesia, yang kekuatan hukumnya cenderung lemah dibandingkan dengan Undang-Undang seperti pada Malaysia. Tidak seperti Shariah Advisory Council pada Malaysia yang merupakan struktur internal bank sentral, DSN di Indonesia merupakan lembaga independen non pemerintah. Sehingga pada Malaysia, tugas dan tanggungjawab dewan Syariah dilaporkan secara periodik kepada bank sentral. Lain halnya di Indonesia, bentuk hubungan DSN dan OJK adalah hubungan koordinasi, dimana DPS melaporkan kegiatan pengawasannya kepada OJK secara periodik.

Selanjutnya mengenai proses pengembangan produk, pada SGF BNM memiliki 
fungsi Shariah research yang berfungsi melakukan evaluasi terhadap kemungkinan produk baru. Sedang di Indonesia, usulan produk oleh manajemen hanya boleh diaplikasikan apabila sudah mendapatkan fatwa DSN-MUI. Sehingga fungsi Shariah research yang ada pada SGF BNM kurang sesuai apabila diimplementasikan di Indonesia, meskipun tidak memungkiri bahwa praktik perbankan Syariah di Indonesia kini juga memerlukan adanya fungsi tersebut, guna mendukung inovasi produk yang lebih beragam.

Lebih lanjut mengenai empat fungsi khusus pada SGF BNM yaitu Shariah Audit, Shariah Review, Shariah Research, dan Shariah Risk Management, bank Syariah di Indonesia tidak memiliki fungsi tersebut secara kelembagaan. Namun secara fungsional bank Syariah menjalankan fungsi tersebut. Seperti dinyatakan oleh salah satu narasumber, bahwa UU Perbankan Indonesia mewajibkan perbankan Syariah untuk memiliki fungsi manajemen risiko yang bertugas dalam mengidentifikasi, melakukan penilaian, mitigasi atas risiko dan melakukan pelaporan. Namun tidak diketahui secara pasti apakah ia juga berfungsi dalam mengantisipasi risiko-risiko yang berkaitan dengan Syariah. Kemudian untuk Shariah research, pada praktiknya manajemen bank mengajukan produk-produk yang belum ada fatwanya. Sehingga bisa dipahami bahwa tidak ada lembaga mengenai Shariah research, namun perbankan secara fungsional melakukan hal tersebut. Oleh sebab itu bisa dikatakan bahwa pembentukan fungsi Shariah research tersendiri pada struktur tata kelola seperti pada SGF BNM juga diperlukan untuk diterapkan pada perbankan syariah di Indonesia. Lebih lanjut, fungsi Shariah review dan Shariah audit di Indonesia berada dalam lingkup tanggungjawab DPS.

Berdasarkan pendapat narasumber, tidak dilakukannya pemisahan fungsi seperti pada SGF BNM, bisa disebabkan oleh keterbatasan SDM yang memiliki dual competency (hukum Syariah dan keuangan) di Indonesia. Dinyatakan oleh Ascarya (2006) bahwa pengembangan perbankan Syariah di Malaysia menerapkan strategi yang terintegrasi dengan dukungan penuh dari pemerintah Malaysia. Pada tahun 1983, sebelum bank Islam didirikan, Undang-Undang disiapkan, sekolah (universitas Islam) didirikan, dan BIMB didirikan. Sehingga dapat dikatakan bahwa keberadaan 4 fungsi khusus terpisah pada SGF BNM didukung dengan melimpahnya SDM yang memiliki dual competency (hukum Syariah dan keuangan).

SGF BNM dinilai kurang sesuai untuk diterapkan di Indonesia, namun bisa dijadikan sebagai dasar acuan untuk segera merancang Framework yang sesuai dengan karakteristik infrastruktur tata kelola Syariah di Indonesia. Menurut Hasan (2011) diperlukan Framework tata kelola Syariah yang layak dan terintegrasi salah satunya untuk memaksimalkan fungsi DPS. Dengan adanya Framework memudahkan untuk dilakukan evaluasi atas kinerja DPS serta memaksimalkan fungsi baik ex ante maupun ex post.

Praktik yang efektif dari tata kelola yang baik membutuhkan semua pihak yang terlibat untuk melaksanakan tanggungjawab sebaik mungkin dengan dukungan infrastruktur dalam bentuk prosedur, proses, dan mekanisme pengawasan. Kemudian, Shariah review internal di bank Syariah harus dikaitkan dengan auditor eksternal dan penerbitan opini tentang kepatuhan Syariah (Mohamad et al., 2015). Lebih lanjut, diperlukan standar yang mengatur format laporan Shariah review pada laporan tahunan 
(Bahari \& Baharudin, 2016). Standar format laporan Shariah review menjadi keniscayaan pada tata kelola Syariah, salah satunya diungkap oleh Aribi, Arun, dan Gao (2015) bahwa pelaporan audit DPS saat ini masih jauh di bawah harapan pemangku kepentingan atau bisa dikatakan pelaporan masih bersifat normatif.

Menurut narasumber, begitu banyak peraturan di Indonesia yang mengatur mengenai Governance, dalam konteks yang berkembang dari masa ke masa. Namun belum ada Framework seperti yang diterbitkan oleh Bank Negara Malaysia. Untuk penyusunan Framework di Indonesia sebenarnya bisa dimulai dengan melakukan mapping peraturan-peraturan yang sudah ada. Mapping didasarkan pada hubungan dan wewenang organisasi yang terkait dengan tata kelola Syariah, misalnya OJK, DSN-MUI, DPS, dan eksternal auditor. Dari 4 pihak tersebut bisa disusun sebagai satu Framework yang berbeda dengan Malaysia.

Lebih lanjut menurut Umam (2016), pendekatan yang paling efektif bagi Indonesia dalam upaya pencanangan GCG adalah dengan melanjutkannya menjadi suatu produk atau ketentuan-ketentuan yang terkandung pada hukum positif. Terkait dengan implementasi GCG pada bank Syariah antara lain perlunya penyempurnaan regulasi dan panduan Best Practice. Di samping itu, juga perlu ditempuh upaya pengembangan dan pengadopsian nilai-nilai Syariah dan kode etik (code of conduct) perbankan Syariah, melakukan edukasi publik dalam rangka mendorong consumer advocacy dan meningkatkan market discipline, serta melakukan pengembangan sistem dan mekanisme pengawasan Syariah yang efektif. Melalui cara-cara tersebut tata kelola bank Syariah akan dapat dilaksanakan dengan sebaik-baiknya.

\section{KESIMPULAN}

Penelitian ini menganalisis infrastruktur tata kelola perbankan Syariah di Indonesia khususnya pada proses Shariah review untuk selanjutnya dilakukan analisis kemungkinan adopsi SGF BNM. Berdasarkan teori, fungsi Shariah review menjadi tanggung jawab DPS, dimana ia memegang peran utama dalam memberikan jaminan atas kepatuhan Syariah pada produk dan operasional perbankan Syariah. Hasil penelitian menunjukkan bahwa terdapat fungsi internal pada perbankan Syariah yang berperan penting dalam mendukung DPS melakukan review Syariah, yaitu fungsi Audit Internal dan fungsi Kepatuhan. Lebih lanjut, fungsi Audit Internal bertugas untuk melaporkan hasil temuan audit cabang, sedangkan fungsi Kepatuhan bertugas dalam mendampingi DPS melaksanakan Shariah review hingga memastikan pelaporan hasil Shariah review yang dilaksanakan oleh DPS. Oleh sebab itu, bisa dikatakan bahwa prosedur, proses, dan mekanisme Shariah review oleh DPS bergantung kepada fungsi internal perbankan Syariah, yaitu fungsi Audit Internal dan fungsi Kepatuhan.

Lebih lanjut ditemukan bahwa adopsi SGF BNM kurang sesuai untuk diterapkan pada perbankan Syariah di Indonesia berdasarkan kecenderungan kondisi infrastruktur tata kelola perbankan Syariah di Indonesia saat ini. Salah satunya karena pada perbankan Syariah di Indonesia belum memungkinkan untuk dilakukan pemisahan tiap unit seperti pada SGF BNM yaitu Shariah Audit, Shariah Review, Shariah Research, dan Shariah Risk Management. Kondisi tersebut disebabkan salah satunya karena sumber daya insani di Indonesia yang memiliki dual competency (hukum Syariah dan keuangan) tidak 
sebanyak yang dimiliki oleh Malaysia.

Namun demikian, industri perbankan Syariah di Indonesia dapat saja merumuskan model Shariah Governance sendiri dengan mempertimbangkan kekuatan sumber daya insani dan beberapa peraturan yang terkait dengan tata kelola perbankan Syariah, misalnya dengan mengedepankan substansi praktik Shariah Governance dibandingkan dengan membuat unit khusus yang mungkin belum optimal fungsinya dalam waktu dekat. Substansi implementasi Shariah Research dan Shariah Risk Management dapat saja mulai dilakukan dengan memfungsikan unit internal audit atau SPI (Sistem Pengendalian Internal).

\section{Saran dan Keterbatasan}

Temuan penelitian ini menunjukkan bahwa perbankan Syariah di Indonesia sudah memiliki peraturan mengenai pelaksanaan Good Corporate Governance baik untuk BUS maupun UUS yang tidak sedikit jumlahnya dalam bentuk Undang Undang (UU), Peraturan Bank Indonesia (PBI), Surat Edaran Bank Indonesia (SEBI), Peraturan Otoritas Jasa Keuangan (POJK), Surat Edaran Otoritas Jasa Keuangan (SEOJK), dan Fatwa DSNMUI. Pemetaan terkait infrastruktur tata kelola pada peraturan-peraturan tersebut dapat dilakukan guna mengidentifikasi baik tugas dan tanggung jawab, hubungan kordinasi, hingga persyaratan untuk setiap organ tata kelola perbankan Syariah. Tujuan dilakukan pemetaan salah satunya adalah sebagai upaya untuk mengkonstruksi SGF yang sesuai dengan karakteristik dan kebutuhan praktik perbankan syariah di Indonesia. Melalui keberadaan SGF, struktur hubungan dan tanggung jawab tiap organ pada tata kelola perbankan Syariah dapat terdefinisi dengan jelas seperti pada SGF yang diterbitkan oleh Bank Negara Malaysia. Kejelasan struktur hubungan serta identifikasi tugas dan tanggung jawab yang disediakan oleh SGF dapat menjadi panduan setiap organ tata kelola dalam melaksanakan tugasnya, lebih lanjut hal tersebut memudahkan regulator atau pihak berkepentingan lainnya untuk menilai efektivitas dan melakukan evaluasi atas kinerja tata kelola tersebut.

Penelitian menggunakan data sekunder berupa pengungkapan mekanisme pelaksanaan tugas dan tanggung jawab DPS khususnya Shariah review atas operasional bank Syariah pada laporan tahunan, dimana hal tersebut memerlukan pembuktian yang lebih mendalam. Oleh sebab itu, perlu dilakukan penelitian dengan pendekatan empiris guna mendapatkan informasi substantif atas pelaksanaan tugas dan tanggung jawab DPS termasuk hubungan kordinasi dengan struktur internal perbankan Syariah dalam melaksanaan Shariah review.

\section{DAFTAR PUSTAKA}

Adiono, C. L., \& Sholihin, M. (2014). Analisis Pengungkapan Tata Kelola Bank Syariah di Indonesia. Jurnal Keuangan dan Perbankan, 18(2), 268-77. doi:10.26905/jkdp.v18i2.802

Aribi, Z. A., Arun, T., \& Gao, S. (2015). Accountability in Islamic Financial Institution: The Role of the Shari'ah Supervisory Board Reports. Journal of Islamic Accounting and Business Research, 10(1), 1-27. https://doi.org/10.1108/JIABR-10-2015-0049

Ascarya, A. (2006). Comparing Islamic Banking Development in Malaysia and Indonesia: Comparing Islamic Banking Development in Malaysia and Indonesia: Lessons for Instruments Development. Paper Presented on Periodic Discussion Directorate of 
Monetary Management Bank Indonesia, 1-61

Bahari, N. F., \& Baharudin, N. A. (2016). Shariah Governance Framework: The Roles of Shariah Review and Shariah Auditing. Proceeding of the 3rd International Conference on Management \& Muamalah, 375-382.

Darmadi, S. (2013). Corporate Governance Disclosure in the Annual Report An Exploratory Study on Indonesian Islamic Banks. Humanomics, 29(1), 4-23. https://doi. org/10.1108/08288661311299295

Grassa, R. (2013). Shariah Supervisory System in Islamic Financial Institutions New Issues and Challenges : A Comparative Analysis between Southeast Asia Models and GCC Models. Humanomics, 29(4), 333-348. https://doi.org/10.1108/H-01-2013-0001

Hasan, Z. (2011). A Survey on Shari'ah Governance Practices in Malaysia, GCC Countries and the UK Critical Appraisal. International Journal of Islamic and Middle Eastern Finance and Management , 4(1), 30-51. https://doi.org/10.1108/17538391111122195

Hasan, Z. (2014). In Search of the Perceptions of the Shari'ah Scholars on Shari'ah Governance System. International Journal of Islamic and Middle Eastern Finance and Management, 7(1), 22-36. https://doi.org/10.1108/IMEFM-07-2012-0059

ISRA. (2015). Sistem Keuangan Islam Prinsip dan Operasi. Jakarta: PT. Raja Grafindo Persada. Maradita, A. (2014). Karakteristik Good Corporate Governance pada Bank Syariah dan Bank Konvensional. Yuridika, 29(2), 191-204. http://dx.doi.org/10.20473/ydk.v29i2.366

Mohamad, S., Sori, Z. M., \& Shah, E. (2015). Shariah Governance Effectiveness of Shariah Committees in Islamic Banks in Malaysia. SSRN, 1-17.

Mollah, S., \& Zaman, M. (2015). Shari'ah supervision, corporate governance and performance: conventional vs Islamic banks. Journal of Banking and Finance, 58, 418-435. https://doi. org/10.1016/j.jbankfin.2015.04.030

Muneeza, A., \& Hassan, R. (2014). Shari'ah corporate governance: the need for a special governance code. Corporate Governance: The International Journal of Business in Society, 14(1), 120-129. https://doi.org/10.1108/CG-02-2011-0015

Nomran, N. M., Haron, R., \& Hassan, R. (2018). Shari'ah supervisory board characteristics effects on Islamic banks' performance: evidence from Malaysia. International Journal of Bank Marketing, 36(2), 290-304. https://doi.org/10.1108/IJBM-12-2016-0197

Parker, M. (2017). BNM's Syariah Governance. Diakses pada New Strait Times tanggal 28 Desember 2018.

Rama, A. (2015). Analisis Kerangka Regulasi Model Syariah Governance Lembaga Keuangan Syariah Di Indonesia. Journal of Islamic Economics, La Riba, 1(1), 1-15. doi:https://doi. org/10.20885/jielariba.vol1.iss1.art1

Shafii, Z., Abidin, A. Z., Salleh, S., Jusoff, K., \& Kasim, N. (2013). Post Implementation of Shariah Governance Framework: The Impact of Shariah Audit Function Towards the Role of Shariah Committee. Middle-East Journal of Scientific Research 13, 7-11. doi: 10.5829/idosi.mejsr.2013.13.1874

Umam, K. (2016). Perbankan Syariah: Dasar-dasar dan Dinamika Perkembangannya di Indonesia. Jakarta: Rajawali Pers.

\section{Laporan Tahunan}

Annual Report 2017 Bank Syariah Mandiri.

Annual Report 2017 BPD DIY.

Annual Report 2017 BPR Syariah Bhakti Sumekar.

CISI. 2010. Islamic Finance Qualification. London UK.

GCG Report 2017 Bank Syariah Mandiri.

GCG Report 2017 BPD DIY.

Shariah Governance Framework 2011 Bank Negara Malaysia. 